\title{
Lavender Flower/Mandarin Orange Peel Essential Oil-Soybean Oil to Repel Culex sp.
}

\author{
Susy Tjahjani, ${ }^{1}$ Hanan Aulalia, ${ }^{2}$ Genevieve Annishaningrat Zailani ${ }^{2}$ \\ ${ }^{1}$ Department of Parasitology, Faculty of Medicine, Universitas Kristen Maranatha, Bandung, Indonesia, \\ ${ }^{2}$ Medical Undergraduate Study Program, Faculty of Medicine, Universitas Kristen Maranatha, \\ Bandung, Indonesia
}

\begin{abstract}
Diseases including Japanese encephalitis and filariasis can be transmitted to humans by Culex sp. Many methods could be applied to prevent their bites from reducing their population or preventing them from their bites. N, $\mathrm{N}$-diethyl-meta-toluamide (DEET) has been widely used as an effective synthetic repellent, but DEET needs to be applied carefully, especially for children. Other repellents based on natural origin, i.e., Lavandula angustifolia D.C. (lavender) flower and Citrus reticulate L. (mandarin orange) peel essential oil and their combination with soybean oil, were studied in Parasitology Laboratory, Faculty of Medicine, Universitas Kristen Maranatha, Bandung on July-August 2018, for their repellent duration against female Culex sp. to find out the optimal formula. It is a simple randomized design with four replications and seven treatments, i.e., negative control, DEET, pure essential oil, pure soybean oil, three kinds of combination of essential oil and soybean oil in various ratios. The study was carried out using the arm in the cage method against four human arms, following Fradin and Day. The data were analyzed using ANOVA, continued with Tukey HSD with $\alpha=0.05$. The result shows that DEET has the longest duration ( $\mathrm{p}=0.000)$, the combination of each essential oil with soybean oil in 1:2 ratio had longer duration than the pure essential oil $(p=0.000)$, soybean oil $(p=0.000)$, and other combination ratios $(p=0.000)$. It was concluded that a mixture of $L$. angustifolia D.C. flower/C. reticulata L. peel essential oil with soybean oil in a certain ratio was the ideal preparation to repel Culex sp.
\end{abstract}

Keywords: Citrus reticulate L. peel, Culex sp., essential oils, Lavandula angustifolia D.C. flower, repellent, soybean oil

\section{Campuran Minyak Atsiri Bunga Lavender/Kulit Jeruk Mandarin-Minyak Kedelai untuk Menolak Culex sp.}

\begin{abstract}
Abstrak
Beberapa penyakit termasuk Japanese encephalitis dan filariasis dapat ditransmisikan ke manusia melalui gigitan nyamuk Culex sp. Banyak cara dapat dilakukan untuk mencegah gigitan nyamuk ini, baik dengan mengurangi populasinya atau mencegah gigitannya. $N, N$-diethyl-meta-toluamide (DEET) telah digunakan secara luas sebagai repellent sintetik yang efektif, tetapi pemakaian DEET harus dilakukan dengan hati-hati khususnya pada anak. Repellent lain yang berasal dari alam, yaitu minyak esensial bunga Lavandula angustifolia D.C. (lavender) dan kulit buah Citrus reticulate L., serta campurannya dengan minyak kedelai telah diuji durasi proteksi terhadap Culex sp. betina sehingga diperoleh formula repellent yang optimal. Penelitian dilaksanakan di Laboratorium Parasitologi, Fakultas Kedokteran, Universitas Kristen Maranatha, Bandung pada Juli-Agustus 2018 dan menggunakan desain simple randomized dengan empat replikasi dan tujuh perlakuan, yaitu kontrol negatif, DEET, minyak esensial murni, minyak kedelai murni, dan tiga macam rasio campuran minyak esensial dengan minyak kedelai. Pengujian menggunakan metode lengan dalam kandang menurut Fradin dan Day dengan empat lengan sebagai empat replikasi. Analisis data menggunakan ANOVA, dilanjutkan Tukey HSD dengan $\alpha=0,05$. Hasil penelitian menunjukkan bahwa DEET memiliki durasi proteksi paling lama $(\mathrm{p}=0,000)$, durasi proteksi kombinasi minyak esensial dengan minyak kedelai rasio 1:2 lebih panjang dibanding dengan minyak esensial murni $(\mathrm{p}=0.000)$, minyak kedelai $(\mathrm{p}=0.000)$, dan rasio kombinasi lainnya ( $\mathrm{p}=0.000)$. Simpulan, rasio tertentu campuran minyak esensial bunga L. angustifolia D.C./kulit buah C. reticulata L. dengan minyak kedelai merupakan sediaan ideal untuk menolak Culex sp.
\end{abstract}

Kata kunci: Bunga Lavandula angustifolia D.C., Culex sp., kulit buah Citrus reticulate L., minyak esensial, minyak kedelai, repellent

Received: 1 March 2020; Revised: 9 July 2020; Accepted: 17 November 2020; Published: 31 December 2020

Correspondence: Prof. Dr. Susy Tjahjani, dr., M.Kes. Department of Parasitology, Faculty of Medicine, Universitas Kristen Maranatha. Jln. Surya Sumantri No. 65, Bandung 40164, West Java, Indonesia. E-mail: susy_tjahjani@yahoo.com 


\section{Introduction}

Mosquito bites can spread many diseases. That is why preventing these bites can reduce the disease's prevalence. Preventing the diseases is better and more important than curing them, while effective vaccines for viral and parasite mosquito-borne diseases are still not yet available. Some of these diseases are fatal or can reduce the productivity of the host. Culex sp. can spread Japanese encephalitis ${ }^{1,2}$ and filariasis, specifically lymphatic filariasis, in an urban and semi-urban area. ${ }^{3}$ Many methods can be taken to prevent the Culex sp. bites either reduce the mosquito population or prevent their bites against humans using mosquito repellent. N, N-diethylmeta-toluamide (DEET) has been widely used as a synthetic repellent, and it is effective in preventing these bites. ${ }^{4,5}$ However, DEET might have a toxicity threshold, ${ }^{6}$ and its application, especially for children, must be carefully done. ${ }^{5}$

Alternatively, essential oils as volatile oils which contain secondary plant metabolites and have pungent odors have shown potential repellent activity against many arthropods. The metabolites found are monoterpene (alphapinene, cineole, limonene, eugenol, terpinolene, citronellol, citronellal, camphor thymol) and sesquisterpenes. ${ }^{7}$ Essential oils as a natural product have another benefit because they are degraded rapidly, have low toxicity against mammalian. ${ }^{8}$ An essential oil from the lavender flower (Lavandula angustifolia D.C.) contains similar compounds such as pinene, cineol, limonene, linalool, linalyl acetate, geraniol, borneol. ${ }^{9}$ Citrus reticulate L. peel essential oil might act as a repellent because of its monoterpene hydrocarbons compound. ${ }^{10}$ Although these essential oils might act as a repellent, and their volatility might harm the duration.

Several plant-based oils contain fatty acids and, as carriers of other repellents, could increase repellent activity duration. ${ }^{11,12}$ This study aimed to explore the repellent activity of a mixture of lavender (Lavandula angustifolia D.C.) flower/ Citrus reticulate L. peel essential oil with soybean oil in a various ratio against Culex sp. compared to every single compound to find out the optimal ratio against the duration of repellent effect.

\section{Methods}

This method aims to reach effective disease prevention as a guideline of effective formulation and the timing of this repellent reapplication. The study was done in Parasitology Laboratory, Faculty of Medicine, Universitas Kristen Maranatha, Bandung in February-March 2018.

It was an experimental study, the arm in cage method with simple randomized design. It was carried out according to Fradin and Day ${ }^{13}$ using $35 \times 35 \times 35 \mathrm{~cm}^{3}$ cages at $24-32^{\circ} \mathrm{C}$ and $60-70 \%$ relative air humidity.

The 560-second generation copulated female Culex sp. mosquitoes aged 7-24 days, which had never sucked blood, were prepared. They reared in the School of Life Sciences and Technology, Institut Teknologi Bandung. Ten of these mosquitoes, which had been $24 \mathrm{~h}$ fasted, were put in each cage just before each experiment. Lavender (Lavandula angustifolia D.C.) flower and Citrus reticulate L. peel essential oils were products from Lansida, Yogyakarta, Indonesia. The volunteer research subjects aged 22-23 years should not be alcoholics and had to have good personal hygiene. The affected arms should be washed using non-perfumed soap before the examination. Before inserted into each cage, four clean lower arms of the research subjects chose in four replications. One group were treated each with $1 \mathrm{~mL}$ of water (treatment 1) on day 1, pure essential oil (treatment 2) on day 3, soybean oil (treatment 3) on day 5, a mixture of essential oilsoybean oil in 1:1 ratio (treatment 4) on day 7 , a mixture of essential oil-soybean oil in 2:1 ratio (treatment 5) at day 9, a mixture of essential oilsoybean oil in 1:2 ratio (treatment 6) on day 11, and 15\% DEET lotion (treatment 7) on day 13.

The duration in minutes between the first insertion until the first mosquito landing was recorded. These data were analyzed using ANOVA continued with Tukey HSD with $\alpha=0.05$.

The study has been ethically approved by the Research Ethics Committee of Faculty of Medicine, Maranatha Christian UniversityImmanuel Hospital with the certificate number is 100b/KEP/III/2018.

\section{Results}

Duration of repellent activity of the combination of lavender (Lavandula angustifolia D.C.) flower essential oil and soybean oil was shown in Figure 1. According to Figure 1, DEET had the most prolonged duration of repellent effect among others $(p=0.000)$, lavender-soybean oil 1:2 had 


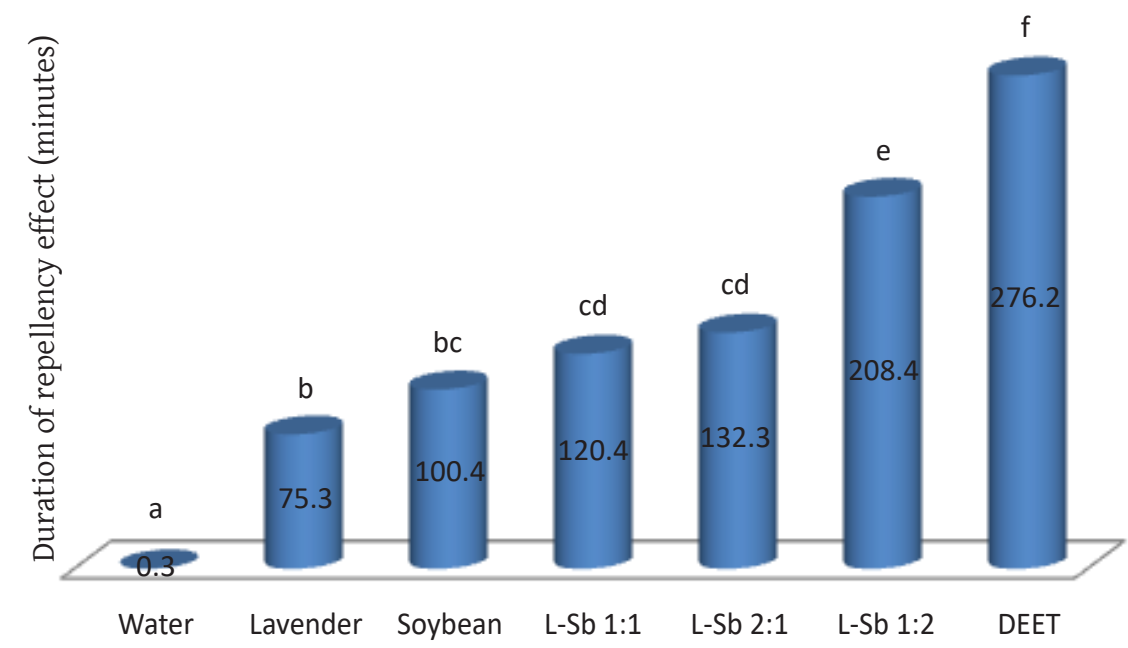

Figure 1 Duration of Repellent Activity of Mixture of Lavender (Lavandula angustifolia D.C.) Flower Essential Oil and Soybean Oil

L-Sb 1:1= mixture of lavender flower essential oil-soybean oil in 1:1 ratio, L-Sb 2:1= mixture of lavender flower essential oil-soybean oil in 2:1 ratio, L-Sb 1:2= mixture of lavender flower essential oil-soybean oil in 1:2 ratio. The same alphabet above the bar means no significant difference ( $p>0.05)$

less duration than DEET $(\mathrm{p}=0.000)$ but was the longest one among the rest $(\mathrm{p}=0.000)$. The other preparation containing soybean oil had the same repellent duration as each other. The lavender flower essential oil had the same duration as soybean oil $(\mathrm{p}=0.302)$.

The duration of repellent activity of the mixture of Citrus reticulata L. peel essential oil and soybean oil was shown in Figure 2. According to
Figure 2, DEET had the most prolonged duration of repellent effect among others $(\mathrm{p}=0.000)$, Citrus reticulata L. peels oil-soybean oil 1:2 had less duration than DEET $(\mathrm{p}=0.000)$, but was the longest one among the rest $(\mathrm{p}=0.000)$. There was a different duration of repellent effect each other in all these preparations except between Citrus reticulata L. peel oil-soybean oil 1:1 and 2:1.

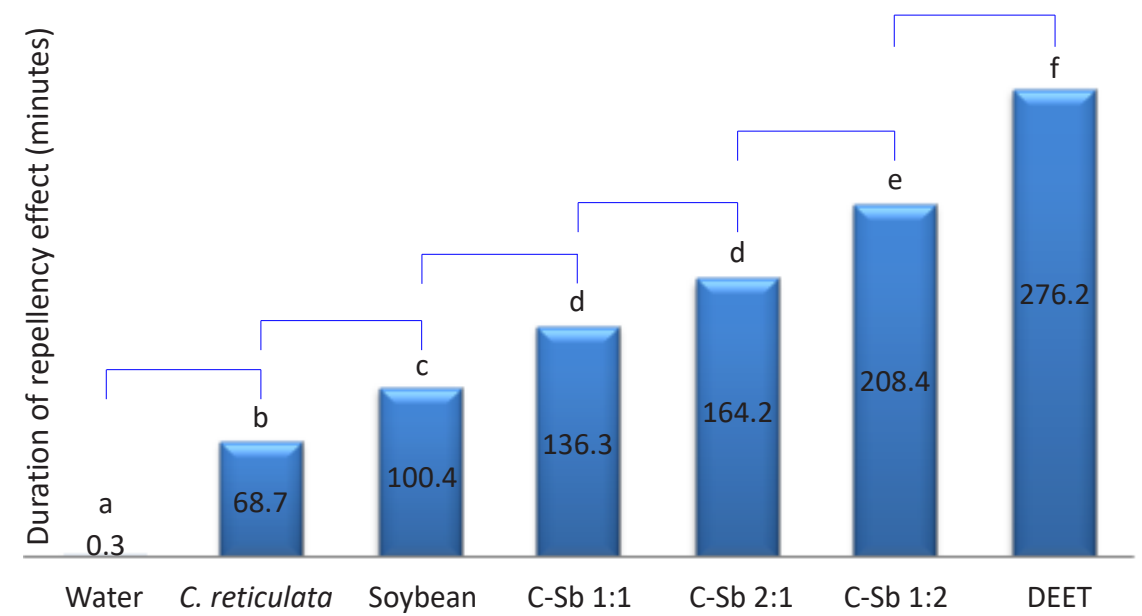

Figure 2 Duration of Repellent Activity of the Mixture of Citrus reticulata L. Peel Essential Oil and Soybean Oil

C-Sb 1:1= the mixture of Citrus reticulata L. peel essential oil-soybean oil in 1:1 ratio, C-Sb 2:1= the mixture of Citrus reticulata L. peel essential oil-soybean oil in 2:1 ratio, C-Sb 1:2= the mixture of Citrus reticulata L. peel essential oilsoybean oil in 1:2 ratio. The same alphabet above the bar means no significant difference $(p>0.05)$ 


\section{Discussion}

To prevent mosquito-borne diseases using mosquito repellent, we should know how human attracts mosquitoes because diseases prevention is better than diseases treatment. Mosquitoes have many receptors in their sophisticated olfactory system (olfactory receptor neuron, ORNs). The olfactory receptor is located at antennal hair and gustatory receptor (contact chemoreceptor) at gustatory receptor neurons (GRNs) located at its labella. ${ }^{14,15}$ They are essential to detect an odor from humans such as lactic acid and $\mathrm{CO}_{2}$ as a primary mosquito attractant. The $\mathrm{CO}_{2}$ was more attractive for Culex sp. than for Aedes sp. ${ }^{16}$ Other studies showed that the primary human odor attractant for Culex sp. was aldehyde compounds from human skin such as nonanal, octanal, and decanal in a certain ratio. ${ }^{17}$ Repellent works by inhibiting the complex olfactory pathway so that they are not sensitive again to detect the attractant odor. ${ }^{18}$ Inhibitory volatiles, such as the essential oils, could work as repellent. ${ }^{18}$

DEET also has repellent activity in several ways, smell through the odorant receptor, ingestion through the gustatory receptor, and contact through mosquito's tarsi. ${ }^{19}$ DEET also stimulates an allosteric site of gustatory receptor neurons. ${ }^{14,20}$

The common compounds containing essential oils that have repellent activity are monoterpenes such as alpha-pinene, cineole, limonene, eugenol, and terpinolene citronellol, citronellal, camphor, and thymol. ${ }^{7}$ Lavender flower essential oil may act as a repellent because it consists of pinene, cineol, limonene, linalool, linalyl acetate, geraniol, borneol, and tannins. ${ }^{9}$ Monoterpene hydrocarbons as major compounds of Citrus reticulata L. peel essential oil may be responsible for its repellent effect. ${ }^{10}$ A monoterpene such as citronellal demonstrates repellent activity through the gustatory receptor neuron ${ }^{21}$ besides through interaction with TRPA1 channels and olfactory co-receptor Orco. ${ }^{22}$

DEET showed a longer duration of repellency. This longer duration might be caused by the more mechanism of DEET's action compared to the natural essential oils. DEET could act by three mechanisms: smell, ingestion, and also through contact via its tarsi. ${ }^{19}$

The mixture of the lavender flower essential oil, as well as Citrus reticulata L., peel essential oil with soybean oil, especially in 1:2 ratio, showed the most effective repellent among others except against DEET. Long-chain fatty acid content in soybean oil might be responsible for it because this fatty acid prevents evaporation of the essential oil ${ }^{11,12}$ and could prolong a repellent activity. Further studies are needed to explore why for both essential oils, the mixture in 1:2 ratio with soybean oil had the longest duration. To achieve the longer duration of this repellent effect, studies are also needed to explore whether any other ratios are better than this ratio and their action mechanism.

In this study, soybean oil itself showed repellent activity. Its repellent activity might be caused by reducing evaporation. This action would reduce the water vapor as mosquito attractant. ${ }^{23}$ Another study reported that coconut oil-derived fatty acid also showed even better repellent activity than DEET. ${ }^{24}$ In contrast, another study reported that soybean oil itself had no repellent activity but only supported other repellent's effectivity. ${ }^{11}$ This different result might be caused by the different composition of long-chain fatty acid in this oil originated from different geographic areas.

As shown in Figure 1 and in Figure 2: all of the examined substances had a repellent effect for more than 30 min duration, but DEET was still the longest duration repellent. A similar result was also reported by other study ${ }^{4}$ as well as a repellent study using Citrus grandis. ${ }^{25}$ As an alternative of DEET, a chemical substance, each of these essential oils could be used as a repellent, especially in combination with soybean oil in ratio 1:2, which showed the most prolonged repellency duration against Culex sp. The application of these combinations would protect against Culex sp. bite for enough long duration, i.e.: around 3 hours and prevent the diseases transmitted by the mosquito. It is essential because disease prevention is much better than disease treatment; there is still no vaccine available to prevent viral and parasite mosquito-borne diseases.

The possibility that human diet might influence the mosquito attractiveness need to be kept in mind. It was not easy to completely control the participants' diet because each treatment was carried out in different days.

\section{Conclusion}

A mixture of Lavandula angustifolia D.C. flower/Citrus reticulata L. peel essential oil with soybean oil in a 1:2 ratio might be considered to 
repel Culex sp. bite optimally.

\section{Conflict of Interest}

We state that there is no conflict of interest.

\section{References}

1. World Health Organization. Japanese encephalitis [Internet]. Geneva: World Health Organization; 2019 [cited 2019 June 24]. Available from: https://www.who.int/ news-room/fact-sheets/detail/japaneseencephalitis.

2. Su CL, Yang CF, Teng HJ, Lu LC, Lin C, Tsai $\mathrm{KH}$, et al. Molecular epidemiology of Japanese encephalitis virus in mosquitoes in Taiwan during 2005-2012. PLoS Negl Trop Dis. 2014;8(10):e3122.

3. World Health Organization. Lymphatic filariasis [Internet]. Geneva: World Health Organization; 2019 [cited 2019 June 24]. Available from: https://www.who.int/newsroom/fact-sheets/detail/lymphatic-filariasis.

4. Yoon JK, Kim KC, Cho Y, Gwon YD, Cho HS, Heo Y, et al. Comparison of repellency effect of mosquito repellents for DEET, citronella, and fennel oil. J Parasitol Res. 2015;2015:361021.

5. Centers for Disease Control and Prevention. Fight the bite for protection from malaria: guidelines for DEET insect repellent use [Internet]. Atlanta: Centers for Disease Control and Prevention; 2004 [cited 2019 June 24]. Available from: https://www.cdc. gov/malaria/toolkit/DEET.pdf.

6. Chen-Hussey V, Behrens R, Logan JG. Assessment of methods used to determine the safety of the topical insect repellent N,N-diethyl-m-toluamide (DEET). Parasit Vectors. 2014;7:173.

7. Nerio LS, Olivero-Verbel J, Stashenko E. Repellent activity of essential oils: a review. Bioresour Technol. 2010;101(1):372-8.

8. Geetha RV, Roy A. Essential oil repellentsa short review. Int J Drug Dev Res. 2014;6(2): 20-7.

9. Hui L, He L, Huan L, Xiaolan L, Aiguo Z. Chemical composition of lavender essential oil and its antioxidant activity and inhibition against rhinitis-related bacteria. Afr J Microbiol Res. 2010;4(4):309-13.

10. Tao N, Jia L, Zhou H. Anti-fungal activity of Citrus reticulata Blanco essential oil against Penicillium italicum and Penicillium digitatum. Food Chem. 2014;153:265-71.

11. Campbell C, Gries G. Is soybean oil an effective repellent against Aedes aegypti? Can Entomol. 2010;142(4):405-14.

12. Hieu TT, Choi WS, Kim SI, Wang M, Ahn YJ. Enhanced repellency of binary mixtures of Calophyllum inophyllum nut oil fatty acids or their esters and three terpenoids to Stomoxys calcitrans. Pest Manag Sci. 2015;71(9):1213-8.

13. Fradin MS, Day JF. Comparative efficacy of insect repellents against mosquito bites. New Engl J Med. 2002;347(1):13-8.

14. Dickens JC, Bohbot JD. Mini review: mode of action of mosquito repellents. Pestic Biochem Physiol. 2013;106(3):149-55.

15. Suh E, Bohbot JD, Zwiebel LJ. Peripheral olfactory signaling in insects. Curr Opin Insect Sci. 2014;6:86-92.

16. Jerry DCT, Mohammed T, Mohammed A. Yeast-generated $\mathrm{CO}_{2}$ : a convenient source of carbon dioxide for mosquito trapping using the BG-Sentinel $\AA$ traps. Asian Pac J Trop Biomed. 2017;7(10):896-900.

17. Leal HM, Hwang JK, Tan K, Leal WS. Attraction of Culex mosquitoes to aldehydes from human emanation. Sci Rep. 2017;7(1): 17965.

18. Ray A. Reception of odors and repellents in mosquitoes. Curr Opin Neurobiol. 2015;34: $158-64$.

19. Dennis EJ, Goldman OV, Vosshall LB. Aedes aegypti mosquitoes use their legs to sense DEET on contact. Curr Biol. 2019;29(9):15516.e5.

20. Lee Y, Kim SH, Montell C. Avoiding DEET through insect gustatory receptors. Neuron. 2010;67(4):555-61.

21. Sanford JL, Shields VDC, Dickens JC. Gustatory receptor neuron responds to DEET and other insect repellents in the yellow-fever mosquito, Aedes aegypti. Naturwissenschaften. 2013;100(3):269-73.

22. Kwon Y, Kim SH, Ronderos DS, Lee Y, Akitake B, Woodward OM, et al. Drosophila TRPA1 channel is required to avoid the naturally occurring insect repellent citronellal. Curr Biol. 2010;20(18):1672-8.

23. Tristantini D, Slamet, Stehanie AJ. Study of mosquito attractants for photo catalytic mosquito trap. Int $J$ Eng Technol (Dubai). 
2014;3(1):14-9.

24. Zhu JJ, Cermak SC, Kenar JA, Brewer G, Haynes KF, Boxler D, et al. Better than DEET repellent compounds derived from coconut oil. Sci Rep. 2018;8(1):14053.
25. Manorenjitha MS, Jamil M, Hashim N, Kiong LS, Jaal Z. Repellency effect of white flesh Citrus grandis osbeck fruit peel extracts against Aedes aegypti (Linn.) mosquitoes. Int J Mosq Res. 2017:4(4):88-94. 